\title{
Venture Capital Process: Opportunity Selection, Monitoring, Capital Rationing, and Deal Flow
}

\author{
Waheed CHICKTAY and Brian BARNARD* \\ WITS Business School, University of the Witwatersrand, South Africa
}

\begin{abstract}
The study investigates specific characteristics of the venture capital market: opportunity selection, monitoring, capital rationing, as well as deal flows and channels, in greater depth. It covers a developing market (South Africa) and uses qualitative methodology. Quality of opportunities is generally low, impacting industry efficiency through increased opportunity costs. Markedly about the assessment of applications, is the degree of structure to the process, and intuition involved. At the post investment stage, portfolio companies are managed in a variety of ways, including providing strategic and operational structures and insight, as well as shared services to enhance business functions. In certain cases, capital rationing prevails in the VC market. Deal referral is an important source of opportunities, underscoring the importance of a network and strong reputation. Overall, the VC market is still in its infancy, with a lack of awareness of both its existence as well as its operation. Key recommendations include: 1) improving entrepreneurs' investment readiness, to increase VC market efficiency; 2) considering the use of technology to automate opportunity screening and selection; 3) placing even greater emphasis on the entrepreneur when managing aspects at a post investment stage; 4) the effective use of entrepreneur incentives; 5) more efficient use of online platforms to efficiently source opportunities; 6) further investigating potentially untapped VC market growth potential due to capital rationing; and 7) increasing VC market awareness and attractiveness.
\end{abstract}

Keywords: venture capital, private equity, opportunity selection, monitoring, capital rationing, deal flow

JEL Classification: G32, G12

\section{Introduction}

The Private Equity industry exists on a continuum. At the one end of the spectrum is the less organized Angel Investor (Fenn and Prowse, 1995) - high net worth individuals who invest their own money, time and expertise (Mason, 2006). Angel Investors provide approximately USD196m per year to start-up and expanding companies (Bygrave and Reynolds, 2004). The more organized private equity industry is often defined by the

\footnotetext{
* Corresponding Author:

Brian Barnard, Wits Business School, University of the Witwatersrand, South Africa

Article History:

Received 1 February 2019 | Accepted 13 March 2019 | Available Online 3 December 2019

Cite Reference:

Chicktay, W. and Barnard, B., 2019. Venture Capital Process: Opportunity Selection, Monitoring, Capital Rationing, and Deal Flow.

Expert Journal of Finance, 7, pp.22-38.
}

This paper has previously been included in an open access repository - SSRN. 
stage of finance (Aizenman and Kendall, 2008). Instead of using the term "VC" to refer to venture finance as well as other private deals, Venture Capital (VC) is defined as early and expansion stage deals, while Private Equity (PE) deals include buy-outs, late stage finance, turnarounds, mergers and acquisitions (Aizenman and Kendall, 2008). This study distinguishes between Angels who fund start-ups, early stage VC and late stage PE, while this entire spectrum is referred to as "private equity." Cavagnaro et al. (2017) indicate that the total assets under management of the PE industry was USD3.4 trillion in 2013.

It has been shown that private equity investment increases available capital to both start-up businesses and established companies looking to expand (Fenn et al., 1995). Companies backed by VCs have also demonstrated faster growth, when compared to other finance sources (Davila et al., 2003), while PE has been shown to be instrumental in facilitating growth from start-up into a public company (Kaplan and Lerner, 2010). Additionally, it was found that $\mathrm{VC}$ increases value in companies invested in, through improved productivity and profitability (Tykvová and Borell, 2012).

Private equity has received research exposure, with various areas investigated. These include the value added by VC firms (Fenn and Prowse, 1995; Tykvová and Borell, 2012); the selection process of investment opportunities (Kaplan and Lerner, 2010; Mason, 2006; Morrissette, 2007); the growth potential of these investments (Davila et al., 2003); and post investment monitoring (Kaplan and Lerner, 2010). The outcomes of these studies point to a number of areas as being critical factors of $\mathrm{VC}$ : opportunity selection, particularly in the context of unlimited investment opportunities; growth potential of investments; capital rationing, as limited capital must be allocated to those investments offering the greatest reward to risk ratio; and post investment monitoring.

The potential influence of $\mathrm{VC}$ investment on entrepreneurial activity, economic growth and innovation is clear. Research in VC has primarily involved quantitative methodology. The results and ensuing discussions of these studies are indeed valuable, as they provide key insight into VC. The purpose of the study is to examine specific characteristics involved in the functioning of the venture capital market. It utilizes qualitative methodology, to develop deeper understanding. The specific issues further investigated are:

- Opportunity selection: How do VC bankers select opportunities?

- Monitoring: How do VC bankers manage their investments?

- Capital rationing: How is capital rationed in the VC market?

- Deal flow and channels: How do VC bankers structure and optimize deal flow and channels?

\section{Literature Review}

\subsection{Introduction}

This section aims to consider the relevant literature related to VC, and provide an overview of various areas of interest within the private equity process. Aizenman and Kendall (2008) distinguishes between PE and VC by the stage of investment. VC is involved in the initial stages of businesses growth where seed, start-up, early stage and expansion capital is required. PE refers to the remaining deals, including mergers, acquisition, buyout, late stage, and turnaround. The PE deals are different as they involve functioning (or previously functioning) businesses, which have moved beyond the early growth phase, while $\mathrm{VC}$ is more likely to invest in product development and market entry (Aizenman and Kendall, 2008).

$\mathrm{PE}$ and $\mathrm{VC}$ operate in a manner that addresses the difficulty of small firms accessing finance (Berger and Udell, 1998). This difficulty is born of factors, including that the contracts that these small firms enter into are not public knowledge; they don't issue publicly traded securities; and in fact the smallest firms will often not have audited financial statements that allow them to convey financial performance. These factors contribute to informational opacity and a small business' inability to signal their quality (Berger and Udell, 1998).

In addition, above the value added through capital extended, VC firms also provide expertise in various business aspects (Weidig et al., 2005). This is facilitated through VC funds aligning themselves with the interests of founders or early-stage investors so that opportunistic behaviour and adverse selection is avoided. Further, the VC process includes thorough due diligence and negotiation, followed by capital commitment (Weidig et al., 2005).

In addition to expertise, Carpenter and Petersen (2002) believe that new equity is superior to debt in a number of ways. These include that fact that debt usually requires the provision of collateral and increases the probability of financial distress, while investors' upside returns are limited. However, the existence of capital market imperfections for new equity, including the mentioned information opacity, may result in a substantial premium on external equity (Carpenter and Petersen, 2002).

Capital market imperfections are especially pronounced in high-tech industries, as firms may look to 
maintain information asymmetries to protect proprietary knowledge and ensure returns on innovation (Carpenter and Petersen, 2002). Private equity financing addresses these imperfections, as their post investment management includes extensive monitoring of the firm, while employing tools to address agency and information issues.

The above tools, expertise and initial search for a viable investment incurs significant costs for $\mathrm{VC}$ firms when compared to public equity (Cumming et al., 2011). Therefore, VC firm's willingness to incur these costs to earn risk-adjusted excess returns over public markets will be impacted by the size of the investment, as well as the ease of access (physical distance) to the firm. Further, Aizenman and Kendall (2008) found that countries with a better business environment, along with sophisticated human capital and deeper financial markets to facilitate IPO venture exits, tend to attract greater VC flows.

\subsection{Value Added by Private Equity}

Private equity firms can deliver significant value over the capital they provide (Weidig et al., 2005). Kaplan and Lerner (2010) found that start-ups that receive VC funding are more likely to grow into public companies. The causality is assumed due to the high correlation between these two uncommon events. Tykvova and Borell (2012) note that researchers are generally in agreement that PE creates value by increasing productivity, profitability and governance of their portfolio companies.

Mason (2006) state that most Angel investors are former entrepreneurs who have sold successful ventures, while the rest either have large business senior management experience, or possess expertise in a specialist business area. They therefore look to play a hands on role in their portfolio companies, including through management and functional advice, providing access to networks, strategy, assisting with next round finance, and providing credibility to the operation through their involvement. Sohl (2003) found that most entrepreneurs view the angel investor's business experience as just as valuable as provision of finance.

Rogers et al. (2002) found that, over the past 10 years, the internal rates of return of the top PE firms globally have consistently been double that of the S\&P 500. This is increasingly achieved through improving both the operations of their portfolio companies, as well as through financial engineering. It is therefore felt that the primary reasons for PE firms' success are the managerial discipline and culture of performance they enforce. PE firms tend to focus on a few key initiatives: They have a pre-defined investment thesis and horizon; they hire managers who behave like business owners; they ensure that staff are focused on a few key success indicators; capital is made to sweat with no hesitance to sell, retire or redeploy under-performing assets; and active shareholders are considered central to the venture.

Fang et al. (2015) note that PE firms possess certain skills in deal due diligence, operations, and monitoring of deals post investment. Ljungqvist and Richardson (2003) further argue that PE firm skills are not easily replicated. These include the evaluation and monitoring of entrepreneurs; and accessing an extensive network, built up over years in the industry, to access both additional assistance and finance.

Growing businesses may be exposed to financial distress and bankruptcy, but Tykvova and Borell (2012) found that, for at least three reasons, PE firms are less likely to be linked to these issues. Firstly, a less experienced firm may feel that they have a point to prove and invest in firms who offer greater potential, but are also more risky. Secondly, seasoned firms have greater knowledge and access to a wider variety of tools, including additional finance when a firm approaches bankruptcy. Thirdly, experienced firms have built up a reputation with finance providers which they need to maintain. They are therefore more likely to take precautions to avoid bankruptcy.

However, there is also a counter argument (Tykvová and Borell, 2012). Experienced firms may increase financial risk in their portfolio companies by engaging in riskier activities, which is facilitated by their honed negotiation skills, greater access to information and superior bargaining power. Additionally, seasoned firms have greater access to syndication, where additional perspectives facilitates higher risk investments through improved selection. Furthermore, syndication allows pooling of complementary skills, leading to greater levels of monitoring and superior support, all of which serve to reduce the probability of bankruptcy. Lastly, syndication offers access to more extensive financial resources, providing additional confidence of being able to assist a company in financial distress.

Acharya et al. (2012) found that PE firms' investments delivers higher alphas (a measure of abnormal financial returns relative to a benchmark) when their interaction with management of the portfolio company was more frequent, and when they were able to leverage external support. These initiatives also serve to overcome adversities in the principal-agent relationship through support and monitoring. Typically, top, mature PE firms focus on turnarounds that increase margins significantly and sustainably and in this way create value for their portfolio companies. These improvements require a level of operational knowledge and this may explain the consistent returns that these PE firms are generating. Additionally, public company management 
buyouts (MBO) show that these businesses had "increases in operating income, decreases in capital expenditures, increases in net cash flow, and improvement in working capital management and productivity." These changes were not associated with cost or capital investment reductions, adding credence to the view that operating enhancements can create value in MBOs (Acharya et al., 2012).

Additionally, Acharya et al. (2012) found that PE deals generate abnormal performance when they engage in active ownership practices. These include due diligence, which involve extensive dialogue with various players; drafting strategic plans; potential changes in management; performance incentives linked to specific KPIs; spending significant time in the business up front; and using external support where needed.

Importantly though, Lopez-de-Silanes et al. (2015) note that the skills necessary to add value are not mechanical in nature, making PE firms difficult to scale up. As a PE firm increases in size, its communication costs increase, as partners need to agree on certain directions, and end up being greater than the benefits of greater levels of knowledge. This is supported by Bernile et al. (2007), who argues that a VC makes better use of funds by investing in multiple businesses, which reduces risk and improves the expected return. However, the $\mathrm{VC}$ devotes both time and effort in these businesses and increasing these will reduce the time and quality of each interaction.

Meuleman et al. (2009) note that PE firms can add value in buy outs through innovation facilitation, which may stimulate growth opportunities, besides the expected improved efficiencies. This is especially the case with divisional, family and secondary buyouts where PE firm skills exploit opportunities these changes offer. PE firm skills, as well as its network, together with the type of buy out and whether these are aligned, will determine the degree of value that can be added. In addition, PE firms may develop capabilities to improve entrepreneurial competencies in a particular industry, through continuous involvement in that sector.

\subsection{Selection of Investment Opportunities}

Kaplan and Lerner (2010) argue that VCs spend a considerable time on screening and selection of investment opportunities. This may last several months, and consideration includes "market size, strategy, technology, customer adoption, competition, and the quality and experience of the management team." This is supported by Davila et al. (2003), who found that VCs dedicate substantial resources to researching new technologies, markets, and investment opportunities in these areas.

Lerner (2002) states that VC firms place significant emphasis on the management capabilities of their investment opportunities. Mason (2006) notes that selection is important to manage diversification risk for PE firms. However, angels are less likely to be able to do this, due to the lower number of investments in their portfolio, as well as the fact that they invest into sectors that they are familiar with and therefore tend to have unbalanced portfolios.

\subsection{Selection Process}

Fenn and Prowse (1995) argue that, to avoid adverse selection, due diligence is particularly important in $\mathrm{VC}$, due to the lack of publicly available information on investment opportunities, as well as the information asymmetry between portfolio company managers and $\mathrm{VC}$ firms. They further state that $\mathrm{PE}$ firms receive a considerable number of investment proposals for review, which involves an initial screening to eliminate those not meeting the firm's investment criteria, including industries in which they specialize. Subsequently, business plan assumptions are assessed, taking up to six weeks.

Business angels follow a similar process, although with personal investment criteria, including location, industry and whether they can add value to the business. They conduct a quick initial review of the proposal to justify further time dedication. If it does, a more thorough investigation ensues, including detailed assessment of the business plan, visiting the firm, and research on viability. Angels want to see strong management, and aspects like integrity, honesty and personal chemistry (Mason, 2006). Wiltbank (2005) found that VC firms avoid many of the risks of seed capital by investing in later rounds. They also reduce the time and effort, usually significant, required for due diligence as the ability to assess the deal improves in later stages.

\subsubsection{Selection Criteria}

Morrissette (2007) found that most investment criteria involve the entrepreneur: enthusiasm, trustworthiness, expertise, and potential for sale of the entrepreneur's product, while management quality, potential for growth and barriers to entry are also important assessment criteria. Hindle and Wenban (1999) found that investment quantum and horizon were important, while Aizenman and Kendall (2008) noted location to be critical to minimize travel costs. Above this, Batjargal and Liu (2004) added that an acceptable net present value, defined as present value less initial investment, is a vital selection condition, with deal upside 
and downside, controls, development phase, finance requirement, founder objectives, liquidity and exit also considered important.

VCs and the entrepreneurs they back, face significant selection risk with new firms, including market, product and technology potential, as well as management abilities (Batjargal and Liu, 2004). The latter specifically looks at experience, skills, reputation and integrity. They also face risks with issues such as entrepreneur intentions and behaviour post investment. VCs mitigate these risks by focusing on areas that they have specialist knowledge in, or co-invest with others who have this knowledge, or geographic or information benefits.

VCs tend to focus on the business (market risk), with disagreement on the entrepreneurs' valuation of the firm being the most common reason for not investing, while Angels tend to focus on the entrepreneur (agency risk) (Mason, 2006), although Hindle and Wenban (1999) state that Angels considered both financial and non-financial factors.

\subsubsection{Subjective Factors}

Batjargal and Liu (2004) note that if primary investment selection factors are rated as strong, then relationships between VCs and the entrepreneur may positively influence the investment decision. Mason and Harrison (2003) argue that an entrepreneur's lack of investment readiness often results in an inability to raise finance. Investment readiness included being skilled in presenting their opportunity to investors, where they found entrepreneurs wanting, both in terms of overly emphasising the product and failing to make a business case, including the potential to create wealth. In addition, firms prefer to find that the entrepreneur's personal affairs are separate from the business; key person mitigants; acceptable management expertise; and readiness to partner with an external investor. Interestingly, angels initially only consider personal investment criteria, such as sector interest and knowledge, finance amount required and location; while initial screening intensity may vary depending on the referrer quality.

\subsection{Networks and Channels}

Sohl (2003) argues that due to Angels seeking a degree of anonymity, information on potential investments do not always flow in the most efficient manner. Entrepreneurs will therefore be engaged in time consuming searches for investors, while quality deal flow is not always immediately available to the investor, resulting in encouraging technologies going unnoticed. Due to the requirement for anonymity, Angels tend to employ a less structured approach to obtaining investment opportunities, relying on referrals (Mason and Harrison, 1997) as well as media, personal research and public sources such as lawyers, accountants etc (Mason, 2006).

Business Angel Networks (BANs) (Mason and Harrison, 1997; Mason, 2006) have therefore emerged in an effort to link entrepreneurs and investors, by allowing entrepreneurs access to a number of Angels, while providing anonymity to the latter until negotiation stage. This is supported by Berger and Udell (1998) who also found that non-profit entities have set up "private angel networks" to connect entrepreneurs and investors. Entrepreneurs find VC by providing company information and needs, while Angels who have been "qualified" by the network operator, can search for opportunities that interests them. Wiltbank (2005) adds that VCs carry out various initiatives to establish a network of contacts that may be sources for future deal referrals, including syndication, which facilitates participation of VCs in each other's deals.

\subsection{Estimation of Growth Potential}

Davila et al. (2003) further note that VC backed companies experienced faster growth than companies backed by other sources of capital. The reasons for this may include the skills that VCs bring to existing management teams, improved firm governance and monitoring, as well as their network of contacts, who include functional (accounting, law etc.) service providers. Additionally, access to the VCs broader business partner contacts reduces search costs and assists with start-ups' lack of resources. Further, start-ups' ability to make it through the $\mathrm{VC}$ screening process also serves as a signal to other parties of its inherent abilities, assisting in gaining new employees, customers and strategic alliances.

\subsection{Managing and Monitoring Investments}

Mason (2006) notes that the level of involvement of some Angels in portfolio companies, and that they are involved so early, means that they are seen as part of the entrepreneurial team. Berger and Udell (1998) add that the middle years of a PE fund's life involve active roles in portfolio companies, including consulting, assisting to solve key operational issues and serving as a director.

Agency issues between the entrepreneur and the VC may also arise, where the entrepreneur does not 
perform to a level required to efficiently and effectively run the business (Berger and Udell, 1998). The VC mitigates this by use of up front contracts which include clauses that speak to, among others, production investment; control of and choice of funding; voting rights, board representation and compensation of the entrepreneur. Kaplan and Lerner (2010) support this by noting that VC contracts often include clauses that allows for the entrepreneur to capitalize with good performance, but also for the VC to take control if he doesn't. The specific types of clauses are inserted based on the VCs initial analysis of the business, and may include the ability to replace an under-performing entrepreneur.

VCs often take an active role in creating senior management remuneration packages, as well as replacing these individuals if need be (Fenn and Prowse, 1995). They stay informed of company matters through middle management and assist with acquiring additional finance, important operational issues, strategy formation and capital outlays. VC partners spend an average of one hundred hours a year with each company, and also visit each, where they are the lead investor, nineteen times a year. However, VCs tend to specialize in an industry to leverage this knowledge across investments, and also focus on a geographic area to facilitate frequent company visits. In addition, PE firms will sometimes bring in external management expertise in so called management buy-ins (MBI), where these external individuals buy firm equity (Meuleman et al., 2009). This is in contrast to a management buy-out (MBO) where existing management take a portion of the equity.

Acharya et al. (2012) note significant differences between PE and public company boards of directors. PE directors have greater exposure to cash flow risk through equity holding, and thus have greater incentives, and are empowered to generate value in a shorter time frame. In contrast, public company directors are more exposed to reputational risk, focus on compliance issues and also spend less time with company management than PE firms do. They are also less focused on cost reduction than PE firms.

\subsection{Exiting the Investment}

Berger and Udell (1998) note that the best exit mechanism is generally through a public offering, with VC bankers serving to reduce opacity and choosing optimal timing; followed by a private sale to another company. An under-performing portfolio firm may be sold back to its original owners or liquidated as a last resort. Silbernagel and Vaitkunas (2012), however, stress that mezzanine investments are generally paid back through business profits, equity sale or recapitalization

Berger and Udell (1998) argue that general economic conditions may influence the flow of funds into $\mathrm{PE}$ and debt markets. This is because Angel and VC finance, at the point of origination, is largely determined by valuation forecasts at time of exit. This includes using current public market price/earnings multiples and applying them to the projected earnings at exit. Movements in the present public markets will therefore influence valuations and exit horizons in the present PE market, and therefore flow of funds to the PE industry. Ljungqvist and Richardson (2003) believe that PE funds' willingness to exit their portfolio companies is a function of public market investors' readiness to pay for them.

Acharya et al. (2012) found the PE houses hold onto under-performing investments, looking for better selling opportunities. This is supported by Krohmer et al. (2009), who note that staging of finance rounds positively impacted returns on investment in the early stages of the investment. Investors use the staging to monitor the portfolio company, and provide it with resources or choosing to exit. If monitoring results in more financing rounds or more tranches within financing rounds, it is usually the result of negative performance, and the investor seeking to gain additional control over the portfolio company. However, in late stage investments, investors use staging as a means of possible investment resurrection. If these steps are not taken, the outcome may be the portfolio company investment being written off, resulting in reputation damage for the PE firm and entrepreneur.

\subsection{Investment Mediums and Avenues}

Fenn and Prowse (1995) note the process for PE GPs to raise new funds is expensive and time consuming, especially if they lack significant experience or solid reputation. This is especially so during times of low market liquidity, where PE managers are not easily able to refinance their investments (Franzoni et al., 2012). Their options are to either liquidate investments or accept increased debt costs, reducing their return on the investment.

Interestingly, Mason and Harrison (1997) found that the VC industry has moved from more classic $\mathrm{VC}$, which was involved with start-ups and concentrated on value building; to merchant, which focuses on financial engineering and fees and short term gains. Sohl (2003) therefore argues that a new funding gap has emerged in the early stage of equity financing, as Angels remain involved in start-ups. This gap is partly being filled by "Angel alliances" which are groups of angels willing to consider early stage investments.

Mason (2006) argues that syndicated Angel investing is becoming increasingly significant as an 
investment medium, as the angel market moves to a more organized structure. Angel syndicates reduce inefficiency, while also stimulating investment supply, by making angel investing more attractive through diversification, combining skills, improved post investment management, and facilitating market access for smaller investors.

Fang et al. (2015) found that institutional investors have gradually increased their direct private equity investments, circumventing the PE or VC houses. This is done as a co-investment with a PE or VC house, or exclusively. This strategy is due to both cost savings, as fund managers were earning the premium return generated from private investment; as well as the need for greater control of investments, as PE and VC houses looked at deal selection and timing, the latter being important due to the cyclical nature of PE or VC performance. Direct investment also allows the LPs to add value through management skill, and to actively tailor risk exposure.

Government venture capital is a channel through which policy objectives are driven, but Leleux and Surlemont (2003) argue that if government funds require a below market return in exchange for meeting policy objectives, they may attract the best investments, leaving the under performers for the private sector. This results in inappropriately allocated capital and the creation of barriers to entry in the private VC industry. Important questions on public funding are whether they facilitate VC industry growth or whether it displaces it. Brander et al. (2014) found that government finance coupled with private VC finance, improved the investment outcomes as well as exit performance, when compared to private or government VC alone.

\subsection{Credit Rationing}

Bester (1985) defines credit rationing as a state where finance is not provided to all potential borrowers, even though those who do not receive finance would provide additional collateral or accept higher interest costs. Peneder (2008) states that not all firms have the same level of access to external finance. Small businesses endure significant risk assessment and transaction costs relative to the finance required, while startups do not have an established track record and also generally lack collateral. Investors also account for the fact that early stage ventures are more likely to fail. Innovation businesses face further complexities, due to owners' reluctance to release potentially imitable material, while also having less tangible assets for collateral.

Further, Peneder (2008) notes that the financing decision is dependent on two factors, namely information availability and correctly interpreting the information. Ideally, all projects are assessed on merit, with higher risk projects attracting higher interest rates. However, this is rarely the case, with availability of collateral often being a determining factor in accessing credit. This is because the entrepreneur is not properly able to convey information about project quality, while the investor is weary of moral hazard: post investment, the entrepreneur may reduce effort or pursue objectives to the detriment of investor returns.

Bester (1985) argues that banks reject some borrowers due to incentive and selection effects of interest and collateral. Only higher risk borrowers will accept higher interest rates, while using collateral to mitigate risk reduces bank profit and may result in adverse selection. Bester feels that if banks competed through collateral and interest rates, credit rationing would not occur in equilibrium, as banks decide on these two factors simultaneously as opposed to separately.

\subsection{Conclusion}

The literature review reveals that the VC industry have many intricacies that need to be considered. It has evolved over a period of time and developed greater sophistication and specialisation. Also, it may perhaps have matured to an extent where larger, less risky and more profitable deals are being sought to the detriment of earlier-stage ventures. These and such elements may affect efficiency, and the extent of impact either way would be an interesting avenue to explore.

\section{Methodology}

In order to further examine specific characteristics of the venture capital market - opportunity selection, monitoring, capital rationing, deal flow and channels - semi-structured interviews were conducted with 10 participants. Purposive sampling was used to select the participants. The participants were established VCs, all having extensive experience (all participants far exceeded the study's minimum of at least 3 years), and from established VC firms (funds under management exceeding SAR1.8 billion). A number of angels (2) were also interviewed. The interviews on average lasted 1 hour. The interviews were recorded, transcribed and subsequently coded. 


\section{Results}

\subsection{Opportunity Selection}

\subsubsection{Opportunity Quality}

Opportunities that reach firms are generally not investment ready, especially those presented by less established entrepreneurs, with pitches tending to focus on the business idea as opposed to the business case. Entrepreneurs also tend to lack business pitching skills, especially knowledge of business language and requirements.

The apparent lack of guidance for potential entrepreneurs may be one reason for this, but one experienced participant felt that SA's (South Africa's) entrepreneurship culture hampers opportunity quality. Potential entrepreneurs' understanding of businesses and their ability to spot opportunities is limited, due to education quality, as well as lack of exposure, also partly due to socioeconomic restrictions, both limiting the mind to new possibilities. Feedback to entrepreneurs is therefore considered helpful. At the same time, it may be inefficient for VCs to provide this form of education to entrepreneurs. Moreover, investing in the business and enterprise development sub-market, where the entrepreneur is a supplier to a bigger company, improves the availability of lower risk opportunities, as these entrepreneurs are generally more established, while the bigger company acts as a more secure market.

When assessing high application volumes, a firm is weary of both time and potentially missing a good deal. Most participants agreed that low quality opportunities can be quickly picked up through initial screening that looks at core issues such as market, product, price points, competition and financials. Therefore high opportunity volumes should not affect screening quality, as well as that intensive due diligence may only be done on a specific number of opportunities tied to firm capacity and specialization.

The converse to this is that low numbers of opportunities (with the same quality ratio) results in more time spent searching for investable opportunities. Angel firms will be less concerned with this, as they tend to not only invest for profit, but also for passion, and seek synergies with their outlook.

\subsubsection{Opportunity Selection}

VC firms are more likely to be bound by certain sectors as part of their fund mandate, and some tend to invest in businesses already producing a steady stream of dividends. Angel investors specifically look for businesses where they can add value. They may prefer investing in businesses where they can introduce a ready market. VCs generally like to specialize in particular industries.

The investment assessment process can stretch over about six months, from meeting the entrepreneur (after initial paper assessment) to investment. Most participants agreed that the entrepreneur is the primary consideration, with significant due diligence on this person, who needs to show passion for the business. In addition, the entrepreneur's personality is important in that the possibility of a good working relationship must exist. Further, entrepreneurs are often sourced through a trusted network, where they would have gone through an initial screening process already.

Firms recognize that the entrepreneur will not be the complete package, but the entrepreneur must still present something to work with. The entrepreneur's team and strategy is considered important, but this is also where the firm can add value in terms of assisting with putting the right people in place, as well as formulating a strategy with the entrepreneur. The business idea follows the entrepreneur in importance. There must be potential for growth, while differentiation and inimitability are also key. Linked to this is the market potential, understanding of the market, and the ability to expand into other markets.

\subsubsection{Opportunity Evaluation}

Participants largely agreed that opportunity evaluation is normally a structured process. This may involve understanding the idea, reviewing the business plan, and determining if there is synergy between the firm and entrepreneur. Following this, a more in depth process kicks off, with additional questions and meetings and finally board approval and legal documents.

Structure minimizes the risk of human error and emotion playing a role in investment decisions. However, structure seems to be complemented with intuition, particularly where the VC possesses greater experience. The $\mathrm{VC}$ is able to form a holistic view and assessment of the opportunity more quickly, also by looking at and considering less apparent points. Greater experience naturally implies stronger and more developed intuition, that in turn causes a less structured manner of coming to an understanding of the business. One participant also mentioned that a highly structured process may allow the entrepreneurs to provide responses that they think the firm wants to hear.

One experienced participant, however, emphasized that sequence is important, regardless of structure. 
That is, a stage gate approach, allowing for the firm to more easily weed out pitches which lack important aspects. A participant firm was in fact building a digital screening tool that would permit a stage gate approach without human intervention.

\subsubsection{Objective Versus Subjective Evaluation}

All participants tended to lean towards subjective assessments, while attempting to evaluate as objectively as possible by assessing hard facts. However, entrepreneur and management assessments are strongly subjective, due to uncertainties or unknowns that may sway the investment decision, along with the firm's intuition of the business.

A prospect could make sense on paper, but does not sit well with decision makers. In this way, the objective evidence may be positive, but subjectivity will sway the decision. Greater investor experience may result in more reliance on intuition, even though the opportunity may go through an objective process to ensure process compliance. Subjectivity is also intertwined in objective elements of the evaluation, where for example context to financial numbers could change how these are viewed.

\subsubsection{Proposal Rejection}

Unsurprisingly, almost all participants provided reasons for rejection that were the converse of opportunity selection factors. However, common themes for rejection were lack of evidence of integrity; lack of understanding of commitment necessary to make a business successful, or potentially how big the market is; and the entrepreneur being too focused on the idea and not its marketability. Above the clear focus on the entrepreneur, other factors include high barriers to market entry; whether the product can be rapidly commoditized; an unfocused business strategy; the speed of industry technology change, competitor activity; overvaluation of investments; a management team that is not able to function efficiently; and a venture that the firm has no knowledge of.

\subsubsection{Information Asymmetry}

Entrepreneurs could sometimes intentionally withhold information if they think it may derail the investment. The information can be unintentionally misleading as presented by the entrepreneur. Some participants agreed that greater firm involvement in the business will reduce the chances of information asymmetry, as firms become part of the information gathering process. This will be more likely in the Angel and VC space, where firms get involved early in the life of the business.

If the business is hesitant to provide information at the outset due to fears about IP (intellectual property), especially in the technology space and where concept distinctiveness is emphasized as a requirement for investment, Non-Disclosure Agreements can be signed. One participant stated that the ability of entrepreneurs to provide information requested, and their apparent willingness to do so, will also be strong indicators of investment potential. It may indicate competency or trust issues.

Additionally, firms coming back for their next tranche sooner than expected, and not being able to adequately explain how they spent the previous tranche, is a warning signal that all information was not fully disclosed up front. This is also how this problem can be managed - by delivering funds on a draw down basis, on the back of certain milestones being met. Another participant stated that they guard against information asymmetry by working with people or specialists who will have an idea of what an entrepreneur should be and may not be saying. Where aspects like market and competition risk are mitigated through a secure market, firms may be less concerned about information asymmetry.

Participants generally agreed that regardless of information asymmetry, it isn't particularly easy to determine upfront if an investment will come out as a winner or loser. However, good timelines to work on are a year until the business is able to generate cash, and five to ten years to build something substantial. Qualitative aspects that indicate potential include interest from multiple large stakeholders, all providing an indication of a winning idea.

\subsubsection{Investment Size, Timeline and Proximity}

Most firms have minimum thresholds for investment as absolute returns have to make time invested in the business worthwhile. Further, Angel and VC deals seem to have an investment horizon of about 5-7 years, while PE deals may have shorter horizons of 3-5 years, depending on liquidity needs.

Some participants stated that investment proximity is less of an issue in a digital age. This may especially be the case in the tech environment, as Angel and VC firms, investing in smaller deals with less experienced and knowledgeable entrepreneurs, preferred close proximity to allow for unhindered communication, easy access, and quick checkups, response and intervention. 
Investment size per deal may be influenced by internal targets per stage (start up or expansion) and ensuring investment risk is diversified. Angel firms are less likely to have minimum investment thresholds as they get involved with businesses requiring seed capital.

In addition, Angel firms who primarily seek to add value may find difficulty in exiting within a specific timeframe, deriving personal satisfaction in driving business value. They may also have a strong financial base, and are therefore less concerned about liquidity and investment timelines. The other side of this is that if the business does not see positive change after a specific period, they may exit prematurely.

The existence of "patient capital" in the VC space also lends to the blurring of investment timelines, as firms attempt to get the business to the next stage of growth. Regulation, source of funds and investment mandates may also influence investment size and horizon. If funds are invested for income as opposed to capital gains, investment horizon is less important. This is especially so if the mandate is developmental in nature.

\subsubsection{Co-Investment}

Co-investing offers many advantages, including partnering with people with better knowledge of the industry or asset class being invested in, as well as gaining alternative views on the investment, or ideas on connections between avenues of growth. Firm synergies impacts co-investment value, and one Angel firm mentioned weariness of partnering with a risk averse investor on early stage deals.

Co-investing may also be advantageous as it allows firms to leverage expertise, off-take, or individuals who have connections to facilitate certain processes needed by the business. In a PE scenario, where the investment is an established company, syndicated opinions or perspectives may be less valuable. Suitable partners for co-investing are also not always easy to find.

\subsection{Monitoring}

\subsubsection{Investment Value Add}

In general, firms help the businesses get off the ground. Most participants added value by assisting entrepreneurs with putting a sound strategy in place and aligning it to operations, sometimes by taking seats on their board. Other aspects assisted with include ensuring that there is sufficient expertise within the business; identifying and remedying operational inefficiencies; professionalizing the business, especially financial management and governance; and through initiatives such as sales pipeline and recruiting, as well as immediately availing networks of professionals in different fields.

Through these aspects, the VC firm contributes their expertise, gathered either formally through education, or through experience gained through working on multiple previous business opportunities. In fact, one participant felt that firms, by virtue of being involved in multiple opportunities and therefore having a view of what is or isn't working in these opportunities, can add value by bringing this insight into a business.

In addition, some firms provide back office support, including accounting, marketing, and compliance. The firm may, though, put the building blocks of systems or processes in place for the business, developing the business to fulfill this function on its own later on. Additionally, firms may provide access to other potential markets through their networks. Firms also see themselves as providing an objective view of the businesses, due to them being less, or not at all, operationally involved.

\subsubsection{Entrepreneur Impact and Incentives}

All participants considered the entrepreneur to have a significant impact on business performance, although just over half were against incentivizing the entrepreneur. Their primary incentive should be business ownership and growth, and the entrepreneur requiring additional incentives is considered a significant red flag. One participant pointed out that the entrepreneur's passion should play a big role in the business, and therefore he should not be someone who requires additional incentives, especially when the firm is already taking financial risk and the entrepreneur receives a salary. Further, as the entrepreneur holds the majority share in the business, they must be driving outcomes and have risk and upside in the business, with this already acting as an incentive.

Participants in favour of incentivizing suggested various ways, including through additional funding rounds when milestones are met, as well as the entrepreneur being able to buy back equity earlier. A firm may sell this equity back at a discount, if the expected capital growth has been exceeded. An Angel firm made the point that incentives are important, when considering the ups and downs that an entrepreneur typically experiences.

Another participant stressed that incentives should be thought of as part of a toolkit and be aligned to the goals of the entrepreneur, which could vary depending on their life stage. Therefore, capital growth may 
not motivate the entrepreneur, which is not an alien notion if one considers how differently Angel and PE firms are driven. Additionally, if an entrepreneur performs to expectations without incentives, they can be incentivized to drive further performance - setting milestones which could be rewarded by an additional profit share or share claw-back.

\subsubsection{The Firm's Impact on the Business as Investment}

All participants felt that firms significantly impact the growth of businesses that they invest in, especially in early stage businesses and through the value they add outside of finance. Importantly, besides the knowledge imparted and general advisory services, many activities the firm provides has an explicit cost which the business may not have been able to otherwise afford.

However, firms do not necessarily explicitly measure their value add. Because of the obvious need for the services they provide, business growth and growth in equity value is taken as a measure of their impact. Firms also look at aspects that are almost certainly the result of their involvement, such as opening doors for additional markets through networks.

Additionally, firms may have specific metrics for business aspects that they specifically look at. One participant, however, was emphatic that the measure of firm contribution will be that the business reaches the stage which the firm objectively set as an exit stage. This would indicate that the value that the firm saw in the business has been realized.

\subsubsection{Managing Below Expectation Investments}

Participants provided a wide range of responses on why businesses perform below expectations, as well as how these investments are managed. One participant felt that the timing of the launch of a product may impact its success - is the market and economic cycle ready for it, and if not, is the business able to sustain itself until they are? Additionally, entrepreneurs may take advantage of the development expertise provided by the firm - in this way perhaps not focusing on growth, but rather perfecting their product.

Further issues affecting business performance are insufficient expertise of the business management, with the firm also unable to provide this; the entrepreneur's ability to stay focused on their business, although the reasons for this will often be of a personal nature; over reliance on one or two customers for revenue, which has catastrophic implications if one customer leaves; and entrepreneurs not being prepared and willing to take corrective action if their initial strategy is not working as planned. One participant stressed that firms should spread investment across multiple rounds, with milestones unlocking additional funds, to avoid the complacency resulting from lack of stress, including the stress of having to grow to unlock further funds.

Firms try being somewhat objective with refinance, stressing they will provide additional equity if this may result in additional value being generated, or if cash is needed for the business to move over a hurdle or grow to reach a position of stability, but not if the business is not following a strategy needed to ensure its survival and growth. However, the approach may sometimes be less objective than desired, because of how personally invested individuals in firms may get in the businesses they support, and providing more funding when a business is failing may further indebt it without finding an additional growth path. Additionally, VC companies who use third party capital may be more inclined to keep a business afloat, as they are still able to draw additional performance fees from a business that remains afloat.

Firms may also hold on in hope of a possible turnaround. The factors influencing this may not be very obvious, even to the firm itself, although decisions are aided by discussions with networks on the business prospects, while firms also look for signs in the market and broader economy, and what customers are saying. However, greater vested interest from the entrepreneur through security, for example, may aid a decision to further invest, as this may be seen as alignment of interest.

\subsubsection{Investment Monitoring}

Monitoring, or post investment management and support, involves a variety of activities, including conversations with the entrepreneur about various business activities, and potentially involving firm networks. Conversations might be related to strategy at the beginning, but may progress to more operational matters. There were specific differences in how Angel investors, VCs and PE firms spent time on monitoring. Angel investors seemed to be very involved in businesses invested in, even co-locating these businesses, allowing for easy sight of cues that demonstrate business health.

One Angel investor spends most of his time with entrepreneurs, discussing events in their personal and professional life, with the aim of managing factors which may later have an impact on the business. A second Angel investor mentioned that he spends large parts of his time on specific business elements, including signing on new customers or debtor book movements. 
PE (later stage VC) firms tended to primarily monitor business targets/milestones, although one PE firm mentioned that the entrepreneur relationship was mainly monitored, with quantitative aspects left to automated monitoring. PE firms seem to spend less time with the businesses they invest in, which speaks to them investing in more mature businesses with a management team that should be able to handle many of the issues that early stage VCs or Angel firms are required to involve themselves with directly.

In the latter spaces, some firm resources may be deployed into a business on a full time basis, although these resources mainly spend about half their week on monitoring and assistance. Firms sometimes found that they were aligned to business operations to such a high degree that monitoring activities happen informally, and that time spent on monitoring depended on what is required to develop the business.

\subsubsection{Investment Complexities}

Most participants felt that managing the entrepreneur/management team constitutes the biggest complexity, as different individuals will require different approaches. This is especially the case where firms look to guide entrepreneurs to a solution, rather than provide the solution to them, and complexities include how strategic advice is understood, unwillingness to implement this advice, as well as getting entrepreneurs to think differently, such as corporatizing their business.

An additional issue to consider is that when businesses invested in are liquidated, the relationship of the firm with the business could be interrogated, including the degree of influence the firm may have had and the role they played in the final business outcome. Lastly, at due diligence stage, the firm may lack knowledge on the specific concept being invested in, which can be especially significant in the technology sector.

\subsection{Capital Rationing}

4.3.1 The Need for Capital Rationing

Capital rationing is ubiquitous across VC, although restricted investment mandates may actually result in a shortfall of opportunities. Capital rationing is especially present in the self-funded angel environment, where an investor could be fully committed. However, some angels then use co-investment, depending on the type of investment and whether strategies are aligned.

Angel investors in particular will also consider the proportion of a new investment to their total personal portfolio, passing on an attractive opportunity. However, Angels generally more actively seek out investments and are therefore less likely to be presented with an opportunity that may be a potential winner, and not have the funds for it.

Calls for applications would therefore see greater capital rationing, especially in the PE market where one would expect a greater number of opportunities, due to the prevalence of established businesses. Additionally, a newer firm without a track record to attract institutional funds may find a need for rationing. Lastly, time may also be an investment constraint as firms are only able to assess a certain number of applications in a timeframe that would make investing viable. A number of VCs mentioned that they could increase (double) their operations, if they had access to more funds.

\subsubsection{Return on Investment}

Firms tend to seek specified risk-reward ratios, although the quantum invested may override this need. Firms may be willing to a take a higher risk on a smaller amount invested. Additionally, firms generally do not request collateral from businesses to mitigate risk, although one participant mentioned that cession over shares owned by the entrepreneur is considered, if loans are provided above equity investment.

One participant stated that they would seek a return that is commensurate with the effort put into an opportunity, even though this effort should reduce risk. Additionally, firms may look for compensation for higher risk taken over a short period of time, by requiring return structures that accommodate for this. Firms may sometimes deal with risk and reward differently, as reward could be being part of something that may have significant impact on society, or enhancing reputation through pulling off an investment that is of higher risk and impact.

\subsection{Deal flow and Channels}

\subsubsection{Deal Flow Maintenance}

Most investments originate through personal or professional networks built up through experience and reputation. This reliable, extensive network speaks to an element of trust and pre-vetted proposals, as these networks understand what firms require and look for. One participant spoke of establishing relationships with off-takers, thereby obtaining deal-flow both within the off-taker's supply chain, as well as possibly outside of it. 
Angel firms in particular may actively seek new businesses to invest in through their networks, as opposed to getting passive referrals. Firms with less experience, and thus reputation, or firms looking to expand, are also likely to depend on active deal sourcing, including through business events or online platforms. Firms operating in, or wanting to enter markets with little knowledge of VC, would also use advertisements, and network with professionals, like accountants, to ensure that these referral sources are aware of the $\mathrm{VC}$ avenue.

\subsubsection{Online Channels}

Most participants felt that online channels are of poor quality, with no gate keeper for quality, and are used for idea pitching, rather than for pitching business opportunities. The quality of online platform pitches may be related to SA VC infancy - many entrepreneurs don't understand the space nor requirements for funding. It may also be a function of education and entrepreneurial culture.

For experienced firms with access to sanitized leads through personal networks, where quality is known upfront, online platforms are often not worth the time needed to go through the opportunities listed, in order to find the one or two that are worth further investigation.

However, one participant felt that online channels that require the entrepreneur to pay to list their opportunity, tend to have better quality opportunities, as the payment acts as an initial quality gate-keeper. Additionally, those that allow for filtering certain criteria, improve deal search efficiency, although criteria definitions are open to interpretation. However, these platforms, while inefficient, could provide an idea of what opportunities exist in the market, and an idea of potential pipeline.

\subsection{The Venture Capital Market \\ 4.5.1 Investment Illiquidity}

Illiquidity can be an issue if the business invested in does not generate cash in the expected time frame. The firm will probably also be spending more time with the business than expected, thus redirecting resources expected to work on growing other investments. However, firms also stagger investments, depending on exit strategies and expected dividend flows. Firms also reserve a portion of capital invested, as illiquidity is seen as a given in $\mathrm{VC}$.

PE (late stage VC) firms are more likely to invest in cash generating businesses with dividend policies. Illiquidity will therefore be a bigger factor in the Angel and early stage VC spaces, as these investments are less likely to be cash generative. VC firms can take advantage of certain fund restrictions, limiting investor withdrawal for a certain period, and are also able to use dividends generated in this period to shore up cash reserves. In addition, $\mathrm{VC}$ and $\mathrm{PE}$ firms earn fees on the management of external funds, which helps firm liquidity.

Illiquidity, also as a proxy for VC market investor/ money supply, can impact VC market growth. A relatively low number of SA investors have the means to invest in $\mathrm{VC}$. This is further aggravated by the fact that the $\mathrm{VC}$ space is perceived as risky, thereby attracting only a small percentage of an individual investor's wealth. Further, co-investing may help to resolve illiquidity, but this is not always an option for niche players.

\subsubsection{VC Market Competition}

Competition is seen to a greater extent in the PE space, as opposed to the VC or Angel space. However, $\mathrm{VC}$ competition is increasing, although less so for niche firms. The former may be due to government facilitating investments, as well as the fact that these firms compete for a small pool of investors.

In addition, as the PE market nears saturation, firms are slowly moving into the VC space. Competition also increases when a good deal is available, although Angel investors are less exposed to this, as they are more focused on growth rather than returns and are therefore not competing for the more obvious investments.

\subsubsection{VC Market: Requirements for Success}

Experience was considered the most important factor required for success. Linked to experience is specific knowledge of what it takes to run a business, specifically someone who has previously been or currently is an entrepreneur. Participants were quite spread on specific opinions. Two participants felt that, where funds are sourced from external investors, reputation, and then network, is the most critical, as investors rely on the firm's ability to add value to investments. However, a counter-point is that experience is tied to reputation - firms with reputed industry experience will attract more funds.

Some felt that experience becomes a critical success factor only once a firm has an established reputation and network, and in fact that experience may be less important, due to the intuitive nature of investment decisions. At the same time, it is expected that experience would improve intuition. One participant 
ranked network as second to experience, seeing reputation as less important. However, a strong network may be critical in a saturated market where opportunities are hard to come by.

Many participants felt that a firm's network is most important, especially where the firm's investable funds are sourced internally, such as with Angel investors, as network then facilitates deal flow as well as the ability to create value for businesses invested in. Besides the above factors, a broad mind-set, or cognitive flexibility, was noted as critical in the VC space.

\subsubsection{VC Market: Entry Barriers}

The greatest entry barrier in VC may be the amount of patient capital needed to start off. However, other factors mentioned include the relative obscurity of the SA VC market, making it difficult to attract investors, as well as attracting good quality entrepreneurs, as they approach fund managers with the best reputation. Additionally, because it is more established, the PE environment is seen to have higher barriers to entry than the VC and Angel market.

\subsubsection{VC Market Cyclicality}

The VC market, while not as temperamental, is impacted by the same sentiment as other capital markets, generally moving in unison with them. However, VC firms are also protected from market movements to an extent as investors are locked in for a particular period. Opportunities specifically, though, should be less cyclical, especially in a more mature market, which will have counter-cyclical industries, thus always offering a firm opportunities. In addition, opportunities in the VC space may in fact move counter to the broader market - a downturn in the economy may result in job losses and spur entrepreneurial drive.

\subsubsection{Capital Markets Impacting the VC Market}

Most participants favoured the notion that other capital markets impact VC. Reasons included the sequential nature of the market: PE sells off into the IPO (initial public offering) or M\&A (merger and acquisition) market, and VC links into PE. Also, other markets act as a valuation reference, and their performance has an influence on PE investor sentiment and liquidity.

The counter argument was that other markets have little effect, as the investment horizon is long enough for events in either market to be separate. Still, this will not necessarily be true for PE players specifically bringing in deals to take to IPO in a shorter time frame. In addition, the firm should believe that they have invested in value which will find a buyer at the right time, regardless of other markets' performance.

\subsubsection{VC Market Developments}

Participants' responses on VC market developments included that Broad Based Black Economic Empowerment offered significant opportunities that is not fully explored. One participant emphasized that there is an under supply of these opportunities and suggested that government play a role in getting more of these opportunities off the ground. Participants also mentioned that there seems to be a greater number of large corporates investing in smaller technology opportunities, which may be related to an increased focus on technology driven corporate growth strategies. Additionally, there is a significant increase in the number of technology opportunities available, while ease of business is improving with the internet facilitating transactions.

\subsubsection{Factors Impacting Growth and Attractiveness of the VC Market}

The primary factors mentioned were lack of clarity around regulation, legislation and generally high levels of red tape in SA. The political environment, such as corruption and anti-investment rhetoric, has a significant effect on the investment climate and the economy's ability to grow, while mismanagement of SA's affairs has had an impact on a variety of factors, including government's reputation.

The PE and VC market suffer from poor exposure and accessibility. For example, the low number of high net-worth individuals, as well as high minimum investments, mean limited flows into investments, including higher risk investments. The fact that the PE industry, especially $\mathrm{VC}$, is still in its infancy and not fully understood, is considered a hindrance. The VC space in particular needs increased focus by government and private firms, as supporting start-ups and established small businesses has been a focus, but this has been lacking for businesses that fall in between. Further, with regards to entrepreneurship as supply factor of VC, support to entrepreneurs is sub-optimal. For instance, the individuals providing support to entrepreneurs, including government officials, generally lack specific entrepreneurial experience and therefore empathy, and also tend to provide support services on their terms, for example, during "office hours" when entrepreneurs are running their businesses. 


\section{Discussion}

\section{Opportunity selection: how do VC bankers select opportunities?}

Opportunity quality is generally a problem, primarily due to factors largely outside of firms' control, such as education and awareness of entrepreneurs. The lack of investment readiness of entrepreneurs impacts the efficiency, maturity and development of the VC industry, as it results in increased opportunity costs that come with assessing large numbers of low quality applications; increased search costs through the establishment of high quality networks or scanning online platforms; time spent on non-core functions; as well as affecting the overall potential of the VC industry.

Firms conduct opportunity assessments in a variety of ways. Still, a structured, and sequential process applies to a large extent. The process is subjective to some extent, and intuition, developed through experience, plays a role. Technology can be used to automate the initial screening process, as the factors and requirements are fairly consistent, and in this way improve and enhance opportunity assessment. Firms should therefore consider investing in basic digital tools for initial assessment, especially if they see a large number of applicants and require an efficient method of removing obvious rejections. The factors that impact opportunity selection and rejection were noted.

\section{Monitoring: how do VC bankers manage their investments?}

Post investment monitoring is fairly standard. Some PE (Angel and VC) bankers especially emphasize the entrepreneur's personal and professional life, to minimize potential negative impact on the business. Managing the entrepreneur may provide the greatest investment complexity. The PE banker thus also requires adequate levels of skills in emotional intelligence, mentoring and coaching.

The notion of incentivizing entrepreneurs brought up interesting discussions, perhaps the most compelling being what actually motivates these individuals. If firms operate based on the notion that an entrepreneur is solely driven by profit growth, their view may be slightly one dimensional, and devoid of an deeper appreciation of human complexity. They may be overlooking inexpensive methods of driving entrepreneurial performance, based on better understanding the entrepreneur at a more personal level, in addition to the professional level.

Managing below expectation investments also came up as a difficult subject. Objectivity seemed to be key here, though, with decision makers on re-investment needing to be as far removed from the business invested in as possible. At the same time, it may serve the business well to have an internal champion when firms are discussing their eventual route.

Some firms are implementing shared services for businesses that they invest in, as a means of providing for the lack of skills in these investments. This could serve as extra annuity income for the firm, while also ensuring that cost per business is minimized as each one does not have to be separately staffed. Another benefit of shared services is that it enables business monitoring, as financial figures and many operational aspects will be filtered through the firm.

\section{Capital rationing: how is capital rationed in the VC market?}

Capital rationing is prevalent, particularly among more expert VCs that may cross paths with more good opportunities than they can take on, and particularly for larger and/ or higher-risk investments. Capital rationing may be reduced through greater co-operation within the industry. This can be in the form of coinvesting with other firms, or through specific government fund initiatives. The latter naturally requires an efficiently run government program. The prevalence of capital rationing points to the likelihood of untapped growth potential within the industry.

\section{Deal flow and channels: how do VC bankers structure and optimize deal flow and channels?}

As firms gain experience and reputation, they are more likely to obtain deal referrals. While they take active steps to develop their networks, less experienced firms may consider establishing relationships within the industry as a means of facilitating co-investment, thereby leveraging on skills they may not currently have, as well as developing their firm's reputation in the market. Online platforms offer an alternative to conventional networks, but generally suffer from opportunity quality. Paying platforms may have higher quality opportunities than free platforms, because of the inherent screening mechanism. Online platforms can be further developed for and aligned to VC.

The venture capital market

The VC industry undoubtedly requires a multitude of competencies, but it seems that a strong network 
and reputation are critical. The VC market is also seen as being in its infancy, and concomitantly awareness of both its existence and operation is low. Proper education and marketing of VC can help to alleviate this. Furthermore, the exposure and accessibility of VC can be improved. Political factors also affect the prospects and prosperity of the industry.

\subsection{Further Research}

The following areas are recommended for further research:

- The efficiency of the VC market, particularly in terms of opportunity screening and selection, and the impact investment readiness has on VC market efficiency.

- The use of technology as part of opportunity screening and selection.

- Capital rationing within the VC market, and whether the VC market is under-funded - whether VCs generally lack funds, and whether there is untapped growth potential in the $\mathrm{VC}$ market, due to the level of funds available to VCs.

- The criteria and requirements to align online platforms to $\mathrm{VC}$.

- VC market maturity (levels) and maturing the VC market - moving the VC market (out of infancy) to higher levels of maturity.

- VC market awareness and accessibility.

- The optimal incentivizing of entrepreneurs.

- The impact of the entrepreneur's personal welfare on VC success.

\section{References}

Acharya, V., Gottschalg, O., Hahn, M. and Kehoe, C., 2012. Corporate governance and value creation: Evidence from private equity. Review of Financial Studies, 26(2), pp.368-402.

Aizenman, J. and Kendall, J., 2008. The internationalization of venture capital and private equity. NBER Working Paper No. 14344. National Bureau of Economic Research.

Batjargal, B. and Liu, M., 2004. Entrepreneurs' access to private equity in China: The role of social capital. Organization Science, 15(2), pp.159-172.

Berger, A. and Udell, G., 1998. The economics of small business finance: The roles of private equity and debt markets in the financial growth cycle. Journal of banking and finance, 22(6-8), pp.613-673.

Bernile, G., Cumming, D. and Lyandres, E., 2007. The size of venture capital and private equity fund portfolios. Journal of Corporate Finance, 13(4), pp.564-590.

Bester, H., 1985. Screening vs. rationing in credit markets with imperfect information. The American Economic Review, 75(4), pp.850-855.

Brander, J., Du, Q. and Hellmann, T., 2014. The effects of government-sponsored venture capital: international evidence. Review of Finance, 19(2), pp.571-618.

Bygrave, W. D. and Reynolds, P. D., 2004. Who Finances Startups In The USA? A Comprehensive Survey Of Informal Investors, 1999-2003. Babson-Kaufman Entrepreneurship Research Conference, University of Strathclyde, Glasgow, 3-5 June.

Carpenter, R. and Petersen, B., 2002. Capital market imperfections, high-tech investment, and new equity financing. The Economic Journal, 112 (477) pp. F54-F72.

Cavagnaro, D. R., Sensoy, B. A., Wang, Y. and Weisbach, M. S., 2019. Measuring Institutional Investors' Skill at Making Private Equity Investments. The Journal of Finance, 74(6), pp. 3089-3134.

Cumming, D., Fleming, G. and Johan, S., 2011. Institutional investment in listed private equity. European Financial Management, 17(3), pp.594-618.

Davila, A., Foster, G. and Gupta, M., 2003. Venture capital financing and the growth of startup firms. Journal of business venturing, 18(6), pp.689-708.

Fang, L., Ivashina, V. and Lerner, J., 2015. The disintermediation of financial markets: Direct investing in private equity. Journal of Financial Economics, 116(1), pp.160-178.

Fenn, G. W., Liang, N. and Prowse, S., 1995. The Economics of the Private Equity Market. Board of Governors of the Federal Reserve System (US). Washington, DC 20551. [online] Available at: https://www.federalreserve.gov/pubs/staffstudies/1990-99/ss168.pdf [Accessed on 11 May 2019].

Franzoni, F., Nowak, E. and Phalippou, L., 2012. Private equity performance and liquidity risk. The Journal of Finance, 67(6), pp.2341-2373.

Hindle, K. and Wenban, R., 1999. Australia's informal venture capitalists: an exploratory profile. Venture Capital, 1(2), pp.169-186. 
Kaplan, S. and Lerner, J., 2010. It ain't broke: The past, present, and future of venture capital. Journal of Applied Corporate Finance, 22(2), pp.36-47.

Krohmer, P., Lauterbach, R. and Calanog, V., 2009. The bright and dark side of staging: Investment performance and the varying motivations of private equity firms. Journal of Banking \& Finance, 33(9), pp.1597-1609.

Leleux, B. and Surlemont, B., 2003. Public versus private venture capital: seeding or crowding out? A panEuropean analysis. Journal of Business Venturing, 18(1), pp.81-104.

Lerner, J., 2002. When bureaucrats meet entrepreneurs: the design of effective public venture capital' programmes. The Economic Journal, 112 (477), pp. F73-F84.

Ljungqvist, A. and Richardson, M., 2003. The investment behavior of private equity fund managers. [online] Available http://citeseerx.ist.psu.edu/viewdoc/download?doi=10.1.1.201.8176\&rep=rep1\&type=pdf [Accessed on 11 May 2019].

Lopez-de-Silanes, F., Phalippou, L. and Gottschalg, O., 2015. Giants at the gate: Investment returns and diseconomies of scale in private equity. Journal of Financial and Quantitative Analysis, 50(3), pp.377411.

Mason, C. and Harrison, R., 1997. Business angel networks and the development of the informal venture capital market in the UK: is there still a role for the public sector. Small Business Economics, 9(2), pp.111-123.

Mason, C. and Harrison, R., 2003. "Auditioning for Money" What Do Technology Investors Look for at the Initial Screening Stage?. The Journal of Private Equity, 6(2), pp.29-42.

Mason, C., 2006. Informal sources of venture finance. In Parker, S., (ed) The Life Cycle of Entrepreneurial Ventures. Volume 2. International Handbook on Entrepreneurship. London: Springer, pp. 259-299.

Meuleman, M., Amess, K., Wright, M. and Scholes, L., 2009. Agency, strategic entrepreneurship, and the performance of private equity-backed buyouts. Entrepreneurship Theory and Practice, 33(1), pp.213239.

Morrissette, S., 2007. A profile of angel investors. The Journal of Private Equity, 10, pp.52-66.

Peneder, M., 2008. The problem of private under-investment in innovation: A policy mind map. Technovation, 28(8), pp.518-530.

Rogers, P., Holland, T. and Haas, D., 2002. Private Equity Disciplines for the Corporation. The Journal of Private Equity, 6(1), pp.6-8.

Silbernagel, C. and Vaitkunas, D., 2012. Mezzanine finance. Bond Capital, pp.1-7. [online] Available at: https://www.bondcapital.ca/wp-content/uploads/pdfs/2016-bond-capital-mezzanine-finance-whitepaper.pdf [Accessed on 11 May 2019].

Sohl, J., 2003. The US angel and venture capital market: Recent trends and developments. The Journal of Private Equity, 6(2), pp.7-17.

Tykvová, T. and Borell, M., 2012. Do private equity owners increase risk of financial distress and bankruptcy? Journal of Corporate Finance, 18(1), pp.138-150.

Weidig, T., Kemmerer, A. and Born, B., 2005. The risk profile of private equity funds of funds. The Journal of Alternative Investments, 1, pp.33-41.

Wiltbank, R., 2005. Investment practices and outcomes of informal venture investors. Venture Capital, 7(4), pp.343-357. 